\title{
Why Stock Returns on Property and Real Estate Companies on BEI?
}

\author{
Isnaeni Rokhayati*, Herwiek Diyah Lestari, Harsuti, Winda Rosadi \\ Faculty of Economics and Business, Wijayakusuma University, Purwokerto \\ *Correspondence email: isnaeni_akbar@yahoo.co.id
}

\begin{abstract}
This study aims to analyze the effect of return on equity, price earning ratio and net profit margin on stock returns. The dependent variable in this study is stock return. While the independent variables are return on equity, price earning ratio and net profit margin. The population in this study are property and real estate sector companies listed on the Indonesia Stock Exchange during 2015-2019. The samples obtained were 28 companies using purposive sampling method. The analytical tool used is panel data regression analysis with the help of the software program Eviews 10. Using the fixed effects model, the results show that the return on equity and price earning ratio variables have a significant positive effect on stock returns. While the net profit margin has no effect on stock returns. These results indicate that the stock return of the property and real estate sector companies will change, which is influenced by the return on equity variable and the price earning ratio variable. The implication of this research is that the company is expected to increase revenue by managing or utilizing the capital owned by the company, increasing total sales and minimizing expenses so that the company gets an increasing stock return.
\end{abstract}

Keywords: Return on Equity; Price earning Ratio; Net Profit Margin and Stock Return

\section{INTRODUCTION}

The rapidly growing capital market will have a significant impact on the economy of a country. The development of the capital market also shows that investors have very good confidence in the Indonesian capital market. The capital market can help meet the capital needs of a company in order to carry out company activities and survive in the global economy. Companies in meeting their capital needs can sell shares to the public in the capital market (Silalahi et al., 2019).

The capital market is usually a meeting place between supply and demand for securities. That's where the individuals with excess funds invest their funds. A person who invests is known as an investor and this is what triggers an investment to occur in a company. As an investor who is a source of funds from a company, they invest their capital in certain companies to gain profits in order to maintain and increase funds for investors themselves. In investing, every investor has high enough expectations to earn big profits for himself so that he can invest his equity in certain companies (Tandelilin, 2010). This means that all activities or actions taken by investors in investing their capital must be done in order to obtain a return (profit). The result of the return or profit obtained from a stock investment is called stock return (Tandelilin, 2010).

The profits obtained by property and real estate companies are quite good because the property and real businesses are businesses that have fast-changing characteristics and intense competition. Companies in the property and real estate sector are companies that have ownership of buildings, buildings and other items attached to structures and land and have rights and interests to sell their ownership. Then the increase in property prices is due to land prices that tend to rise, the amount of land is fixed, while the demand for land will always increase along with the increase in population and the increasing human need for housing, offices, and shopping centers, thus property and real estate companies will get profit. Stock return in this company is influenced by the company's internal factors, namely return on equity, price earning ratio and net profit margin.

The return on equity, price earning ratio and net profit margin variables are interesting to study their effect on stock returns because there is a research gap in previous studies, where in the research of (Malinggato et al., 2018; Hidajat, 2017; Carlo, 2014; Andansari, Raharjo, and Andini, 2016) show that the return on equity variable has a significant positive effect on stock returns. The results of research in different directions are shown by research conducted by (Ristyawan, 2019; Susilowati, 2018; and Manurung, 2019) which shows that the ROE variable has a significant negative effect on stock returns. Research conducted by (Sinaga, 2019; Silalahi et al., 2019; Ningrum, 2019; Susilowati, 2018; Roslita, 2017) shows that the price earning ratio has a significant positive effect on stock returns.

Meanwhile, research conducted by (Wasih and Manik, 2018; Andansari, Raharjo, and Andini, 2016, and Mayuni and Suarjaya, 2018) shows that PER results have a significant negative effect on stock returns. Research conducted by (Dewi, 2019; Roslita, 2017; Bakkara, 2017 and Yuliaratih and Artini, 2018) states that net profit margin has a positive effect on stock returns. Meanwhile, research conducted by (Febriawan and Santosa, 2018; Rosmiati, 2018 and Simanjuntak 2019) stated that net profit margin has a significant negative effect on stock returns. 


\section{Literature Review}

Brigham and Houston (2010) explained that signaling theory is an action taken by company management to provide instructions to investors about how management views the company's prospects. This theory explains that financial statements are used to give positive signals (good news) and negative signals (bad news) to users so that they can be used to predict potential bankruptcy in the future. If the financial statements issued by the company show a positive signal, investors will be interested in investing in the company so that the company's stock return level will increase. On the other hand, if the financial statements issued by the company show a negative signal, investors are not interested in investing in the company so that the level of stock return obtained will be low.

Investment theory is an investment for one or more assets that are owned and then usually for a long period of time with the intention of getting profits in the future. Before we invest or invest, we need sufficient knowledge of investing, experience and business instincts, namely in order to know which shares to buy, sell and which to keep. So that investors can get a stock return in accordance with the conditions.

Stock return is the profit obtained from investment. This means that everything we receive that comes from investing activities is called return (Jogiyanto, 2003). An investor is motivated to invest, one of which is to buy company shares in the hope of making a profit from the investment.

Return on Equity (ROE) is a measure of the company's ability to generate profits using its own capital (Affinanda, 2015). The higher ROE shows the company's performance is getting better and has an impact on increasing the company's stock price. If the stock price increases, the stock return will also increase.

Price earning ratio shows how much investors are willing to pay for each rupiah of reported profit (Putranto and Darmawan, 2018). Through this ratio, the share price of an issuer is compared to the net profit generated by the issuer in a year. By knowing the amount of PER, potential investors can find out whether a stock is classified as fair or not, to find out later whether it will generate profits on stock returns or not.

Net profit margin is a measure of the company's ability to generate profits by comparing profit after interest and taxes compared to sales (Kasmir, 2017). The higher the NPM, this will have an impact on increasing the income that will be obtained by shareholders so that it will increase shareholder profits.

\section{RESEARCH METHODOLOGY}

This type of research is quantitative research with the object of research in property and real estate sector companies listed on the Indonesia Stock Exchange in 2015-2019. The dependent variable in this study is stock return. While the independent variables are return on equity, price earning ratio and net profit margin. The population in this study were 77 companies while the research sample was 28 companies using purposive sampling technique. The types and sources of data used in this study are secondary data, in the form of published sample company financial statements. The analytical method used is panel data regression analysis with the help of software eviews 10 . The best model obtained from this study is the random effect model.

\section{RESULTS AND DISCUSSION}

Based on the results of the analysis using Penel data regression with a random effects model using the eviews program, the following causal results can be obtained:

Table 1. Results of Researcher Data Regression Analysis

\begin{tabular}{ccccc}
\hline Variable & Coeficient & $\begin{array}{c}\text { Standard } \\
\text { Eror }\end{array}$ & $\begin{array}{c}\text { t- } \\
\text { Statistik }\end{array}$ & Probability \\
\hline C & 0,1602 & 0,0528 & 3,0322 & 0,0029 \\
X1 & 0,0331 & 0,0032 & 1,9924 & 0,0322 \\
X2 & 0.0550 & 0,0019 & 2,7125 & 0,0075 \\
X3 & 0,0005 & 0,0011 & 0,4329 & 0,6657 \\
\hline
\end{tabular}

Source: Data processed with eviews program

Based on the results of the analysis explained that return on equity variable has a positive effect on stock returns. The results of the analysis of this study produce a $t$ count value that is greater than the table value $(1.992437>1.65613)$ with a probability level of 0.0322 , which means that ROE has a positive effect on stock returns in property and real estate companies listed on the Indonesia Stock Exchange (IDX) in 2015-2019 years. Companies that have a high ROE value indicate that the greater the company's ability to generate net income by using its capital. In accordance with the signal theory which states that the higher the ROE value generated by the company, the more positive signal the company gives to investors to invest their shares. Thus, the more investors who are interested in investing, the more stock returns will increase.

The results of the analysis of this study are in accordance with previous researchers, namely (Malinggato et al., 2018; Hidajat, 2017; Carlo, 2014; Andansari, Raharjo, and Andini, 2016) which show that the return on equity variable has a significant positive effect on stock returns.

Price earning ratio has a positive effect on stock return. The results of the analysis of this study produce a $\mathrm{t}$ count value that is greater than the $\mathrm{t}$ table value $(2.712593>1.65613)$ with a probability level of 0.0075 , which means that PER has a significant positive effect on stock returns in property and real estate companies listed on the Indonesia Stock Exchange (IDX). ) in 20152019. Where a company that has a high PER value means that the price earning ratio can provide clues to investors on the company's past performance and prospects in the future, because the Price Earning Ratio 
(PER) describes the willingness of investors to pay a certain amount per share for each rupiah earned. corporate profits.

The results of the analysis of this study are in accordance with previous researchers, namely (Sinaga, 2019; Silalahi et al., 2019; Ningrum, 2019; Susilowati, 2018; and Roslita, 2017) which show that the price earning ratio variable has a significant positive effect on stock returns.

Net profit margin has no effect on stock return. The results of the analysis of this study produce a tcount value which is smaller than the $t$ table value $(0.432956<$ 1.65613 ) with a probability level of 0.6657 , so it can be concluded that the net profit margin has no effect on stock returns in property and real estate companies listed on the Stock Exchange. Indonesia (IDX) in 2015-2019. This is because investors in investing do not take into account the NPM variable, because if the NPM value increases, it can be caused by the percentage decrease in sales that is greater than the percentage increase in net profit. The increase in net profit margin does not necessarily have an impact on increasing stock returns obtained by investors. Investors do not pay much attention to the high and low NPM because a high NPM value does not necessarily indicate a good company performance in generating net profit from sales.

The results of the analysis of this study are in accordance with previous researchers, namely Fernando (2018), and Febriawan and Santosa (2018) which show that the net profit margin has no effect on stock returns.

\section{CONCLUSION}

Based on the results of the research that has been done, it can be concluded that the return on equity and price earning ratio variables have a significant effect on stock returns, while the net profit margin variable has no effect on stock returns. The implication of this research is that the company is expected to continue to increase revenue by managing or utilizing the capital owned by the company as well as possible in order to make a profit so that it can attract investors to invest and is expected to maintain the stability of the value of its share price, so that investors are interested in buying it. Further researchers are expected to add other variables such as return on assets and debt to equity ratio.

\section{REFERENCE}

Andansari, Raharjo, And Andini. 2016. "Pengaruh Return on Equity (ROE), Pric earning Ratio (PER), Total Asset Turn OVER (TATO) Dan Price to Book Value $(P B V)$ Terhadap Stock Return (Studi Kasus Pada Perusahaan Manufaktur Sektor Makanan Dan Minuman Yang Terdaftar Di BEI Periode 2008-2014)." Journal of Accounting 2 (2).

Affinanda (2015). Analisis Pengaruh Rasio Keuangan Terhadap Return Saham Perusahaan Dalam Indeks LQ 45 Tahun 2010-2013. (Tesis yang tidak dipublikasikan), Universitas Diponegoro, Indonesia.

Bakkara 2017. "Pengaruh Net Profit Margin, Debt to Equity Ratio Dan Earning Per Share Pada Perusahaan Manufaktur Sub Sektor Otomotif Yang Terdaftar Di Bursa Efek Indonesia Tahun 2011-2015." E-Proceeding of Management 4 (1): 458-68.

Brigham dan Houston. 2010. Dasar-dasar Manajemen Keuangan. Edisi 11, Salemba Empat. Jakarta.

Carlo, 2014. "Pengaruh Return on Equity, Dividend Payout Ratio, Dan Price to Earnings Ratio Pada Stock Return." E-Jurnal Akuntansi Universitas Udayana7 (1): 151-164.

Dewi, Wulan Rahma. 2019. "Pengaruh Total Asset turnover, Net Profit Margin Dan Debt to Equity Ratio Terhadap Return on Equity Pada Industri Sub Sektor Kimia Yang Terdaftar Di Bursa Efek Indonesia Tahun 2012-2016" 13(2).

Silalahi,Eli Sabet, iski Ananda Putri Purba, Lorisa Sihombing, Nazli Fahada Al 2019. "Pengaruh Earning Per Share, Price earning Ratio, Ukuran Perusahaan(Firm Size), Risiko Sistematis (BETA) Terhadap Stock Return (Studi Pada Perusahaan Real Estate \& Property Yang Terdaftar Di Bursa Efek Indonesia."Jurnal Aksara Public 3: 140-147.

Febriawan And Santosa. 2018. "Stock Return Dan Faktor Fundamental Pada Pra- Krisis Ekonomi Global 2008 Di Bursa Efek Indonesia.” Journal Ekonomi DanBisnis

Hidajat, 2017. "Analisis Pengaruh Economic Value Added, Return on Assets, Return on Equity, Dan Earning Per Share Terhadap Stock Return PerusahaanSektor Lq-45 Yang Terdaftar Di Bursa Efek Indonesia Periode 2005-2007." Business Management Journal 7 (1): 62-75. Https://Doi.Org/10.30813/Bmj.V7i1.694.

Jogiyanto, H.M,2003, Teori Portofolio dan Analisis Investasi, edisi 2, Yogyakarta:BPFE UGM.

Kasmir. 2017. Analisis Laporan Keuangan. Jakarta: PT Rajagrafindo Persada Kurniawan, Yohanes, J. (2013). Analisis Pengaruh Earning Per Share (EPS), Debt To Equity Ratio (DER), Return on Asset (ROA), Returnn On Equity (ROE) Terhadap Return Saham (Studi Empirik Pada Perusahaan Real Estate Dan Property Yang Terdaftar DI Bursa Efek Indonesia (BEI) Dalam Pengamatan 2008-2012.

Malinggato, Taroreh, And Rumokoy. 2018. "Pengaruh Current ratio, Debt to Equity Dan Return on Equity Terhadap Stock Return Pada Perusahaan Farmasi Yang Terdaftar Di Bei (Periode 20142016) Influence of Current Ratio, Debt to Equity And Return On Equity On Stock Return In The Pharmaceutical C." Jurnal EMBA 6 (4): 39133922.

Manurung. 2019. “Analisis Pengaruh Rasio Modal 
Saham Terhadap Return Yang Diterima Pemegang Saham." Jurnal Penelitian Manajemen 1 (1): 13-33.

Mayuni dan Suarjaya. 2018. "Pengaruh ROA, Firm Size, EPS, Dan PER TerhadapStock Return Pada Sektor Manufaktur Di Bei." E-Jurnal Manajemen 7 (8): 4063.

Https://Doi.Org/10.24843/EJMUNUD.2018.V07.I 08.P02.

Ningrum, Natalia Ratna. 2019. "Pengaruh Asset Growth, Dividend Payout Ratio (DPR) Dan Price Earning Ratio (PER) Terhadap Stock Return Pada LQ 45 Di BEI Periode 2015 - 2017.” Bisman (Bisnis Dan Manajemen): The Journal of Business and Management 2 (2): 94.

Putranto, A. D., Darmawan, A. (2018). Pengaruh Ukuran Perusahaan, Profitabilitas, Leverage, dan Nilai Pasar Terhadap Harga Saham (Studi Kasus Pada Perusahaan Pertambangan yang Terdaftar di Bursa Efek Indonesia Periode 2010-2016). Jurnal Admisnistrasi Bisnis, 56 (1), 110117.

Ristyawan, Mochammad Ridwan. 2019. "Pengaruh Return on Equity (ROE), Debt to Assets Ratio (DAR), Price to Book Value (PBV) Dan Net Profit Margin (NPM) Terhadap Stock Return Perusahaan Sektor Perkebunan Yang TerdaftarDi Bursa Efek Indonesia Periode 2011-2017." Jurnal Ekonomi Bisnis Dan Kewirausahaan 8 (1): 1-17. Https://Doi.Org/10.26418/Jebik.V8i1.26966.

Roslita 2017. "Pengaruh Manajemen Laba, Ios, Roa, Npm Dan Per Terhadap Stock Return Perusahaan Manufaktur.” Journal Economic 20 (1): 1-11.

Rosmiati 2018. "Pengaruh Likuiditas Dan Profitabilitas Terhadap Stock Return." Journal of Chemical Information and Modeling 9.

Simanjuntak, Santi Warwati 2019. "Pengaruh Struktur Modal, Net Profit Margin (NPM), Current Ratio (CR), Dan Price earning Ratio (PER) Terhadap Stock Return Pada Perusahaan Manufaktur Sektor Industri Barang Konsumsi Yang Terdaftar Di Bursa Efek Indonesia (BEI) Periode 2014-2017 -." Akrab Juara 4 (Mei): 38-54.

Sinaga, Ria Veronica. 2019. "Pengaruh Inventory Turnover (ITO), Debt To Equity Ratio (DER), Return On Asset (ROA), Earning Per Share (EPS), Dan Priceearning Ratio (PER) Terhadap Stock Return Pada Perusahaan Food And Beverage Yang Terdaftar Di Bursa Efek Indonesia". Jurnal ManajemenDan Bisnis 19 (1): $28-47$.

Susilowati 2018. "Pengaruh Current Ratio, Debt to Equity, Price Earning Ratio, Total Assets Turn Over Terhadap Stock Return LQ45." Probank: Jurnal Ekonomi Dan Perbankan 3 (2): 43-51.

Tandelilin, E. (2010). Portofolio dan Investasi Teori dan Aplikasi. Yogyakarta: Penerbit Kanisius.

Wasih dan Manik. 2018. "Pengaruh Return on Asset
(ROA), Net Profit Margin (NPM), Price Earning Ratio (PER), Price to Book Value (PBV) Dan Debt toEquity Ratio (DER) Terhadap Stock Return Pada Perusahaan Manufaktur Yang Terdaftar Di Bursa Efek Indonesia Periode 2014-2016." Jurnal Akuntansi Dan Keuangan2 2016: 1-21.

Yuliaratih dan Artini. 2018. "Variabel-Variabel Yang Mempengaruhi Stock Return Pada Perusahaan Property and real estate Di BEI." E-Jurnal Ekonomi Dan Bisnis Universitas Udayana 5:1495. 